REVIEW

\title{
Improving the management of atopic disease
}

\author{
S T Holgate, G Lack
}

Arch Dis Child 2005;90:826-831. doi: 10.1136/adc.2004.053280

Asthma, wheeze, eczema, and, to a certain extent, rhinitis are very common conditions among children. The prevalence of allergic disease in the general population has increased alarmingly over the past 25 years, particularly in Western industrialised countries. However, it is important to remember that the symptoms often associated with allergy can have other aetiologies. Evidence suggests that in most circumstances, only $30-40 \%$ of chronic allergic-type symptoms are due to allergy. Accurate diagnosis of the presence of allergy is therefore an important issue, particularly given the interventions that such a diagnosis may initiate. In this review, we examine management options for allergy, provide the evidence as to what proportions of patients with common allergic-type symptoms are actually allergic, and list other causes of such symptoms. The importance of allergy testing and the options available are described, particularly with reference to the role of the non-allergist.

See end of article for authors' affiliations

Correspondence to: Dr S T Holgate, Mailpoint 810, D, Centre Block, Southampton General Hospital, Southampton SO16 6YD, UK; s.holgate@soton.ac.uk

Accepted 19 October 2004
A sthma, wheeze, eczema, and rhinitis are very common conditions among children. The prevalence of allergic disease has increased alarmingly over the past 25 years, particularly in Western industrialised countries (fig 1). ${ }^{1-3}$ Also of concern is the "allergic march" a term used to refer to the progression of allergic disease with age. Food allergies that manifest with symptoms such as eczema or immediate hypersensitivity tend to be most prevalent in infants and young children. Conversely, rhinitis and asthma are more common in older age groups.

Allergy is defined as a hypersensitivity reaction to a specific allergen initiated by immunological mechanisms. Allergic reactions are usually mediated by the antibody immunoglobulin E ( $\operatorname{IgE})$, which is produced in response to the presenting allergen. The term atopy, on the other hand, refers to a predisposition to produce IgE antibodies in response to low dose allergens and consequently to develop typical symptoms such as rhinitis, asthma, wheeze, or eczema. Atopy is diagnosed through personal and family history and is confirmed by the presence of high levels of allergen specific IgE in serum or by positive skin prick tests. ${ }^{4}$

\section{DIFFERENTIAL DIAGNOSIS: IMPLICATIONS FOR PATIENT CARE}

When confronted with symptoms typical of allergy, it is important to establish the cause-that is, ascertain whether or not allergy is present and define the specific allergies. However, this is frequently not performed, as the process is regarded as lengthy, expensive and unlikely to provide clinically meaningful information. Instead of opting for an accurate diagnosis, allergy is often assumed, with various medications such as antihistamines and steroid nasal sprays prescribed until an effect is observed.

\section{Does it really matter whether allergy is accurately diagnosed?}

Correct diagnosis facilitates the selection of appropriate management strategies such as immunotherapy or allergen avoidance. Conversely, the value of a negative allergy diagnosis should not be underestimated, as this can circumvent trials of various inappropriate medications, unnecessary avoidance measures (which may be costly, potentially harmful (in the case of food), or impact on quality of life), and allow further diagnostic investigations to be initiated. ${ }^{5}$

\section{Appropriate allergen avoidance Asthma}

Several controlled studies have demonstrated that restricting exposure to house dust and house dust mite significantly reduces asthma signs and symptoms (for example, fewer days of wheeze, reduced requirement for medication, and fewer abnormally low peak flow readings) in children sensitised to these allergens, and results in highly significant reductions in total serum IgE. ${ }^{6-9}$ However, some studies have shown less benefit from this approach. ${ }^{11}$

\section{Rhinitis}

Unfortunately, there are few quality data showing whether allergic avoidance improves outcomes in rhinitis and more studies are required. Of course, patients with seasonal allergic rhinitis only exhibit symptoms during the time of year when they are exposed to specific pollen and will remain asymptomatic during the rest of the year. As seasonal allergic rhinitis and asthma often coexist to produce a continuum of airway disease, the same is true for seasonal allergic asthma. Therefore, it seems logical that reduced allergen exposure would reduce symptoms in patients with perennial rhinitis.

\section{Eczema}

Several studies suggest that the role of dietary avoidance in alleviating atopic eczema is greater

Abbreviations: DBPCFC, double blind, placebo controlled food challenge; IgE, immunoglobulin $\mathrm{E} ; \mathrm{RCP}$, Royal College of Physicians; SIT, specific immunotherapies 


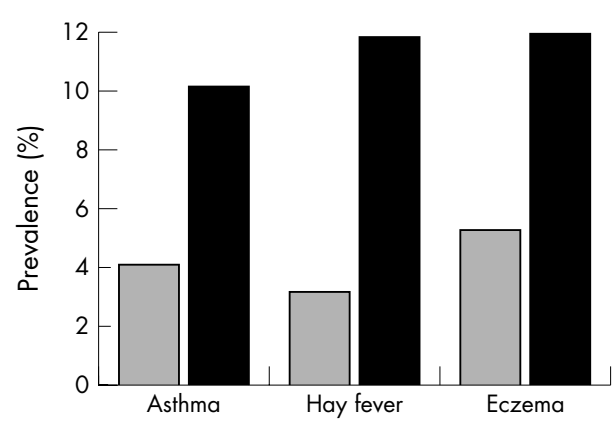

Figure 1 The prevalence of asthma, hay fever, and eczema in two studies 25 years apart. Grey bars, 1964; black bars, 1989. Data from Ninan et al. ${ }^{3}$

than previously thought. A study by Agata and colleagues suggests that symptoms of atopic eczema improve if specific food allergens are eliminated from the patient's diet. ${ }^{12}$ In a double blind, controlled study, Atherton et al reported significant clinical improvement in many children with atopic eczema who received a diet free of egg and cow's milk. ${ }^{13}$ Physicians should be aware that because of maternal intake, cow's milk allergens are of clinical importance even in children with eczema who are exclusively breastfed. ${ }^{14} 15$

\section{Management}

When considering the management of patients with allergictype symptoms, it is important to remember that a large proportion of cases may be the result of other non-allergic processes and will, therefore, respond differently to treatment targeted towards allergic disease. Furthermore, many symptoms from different organs could be caused by single allergen exposure. For example, rhinitis, asthma, and eczema can result from cat allergy. This is important because there are safety concerns regarding steroid loading and the effects of simultaneous administration of steroids through different routes (for example, nasal, inhalational, skin and systemic steroids). In children, this may have a deleterious effect on growth.

The identification of highly atopic individuals gives an indication of the severity of allergic disease. Patients with asthma, for example, with multiple positive skin tests or specific IgEs have more severe asthma than individuals who are monoallergic or oligoallergic. More than $50 \%$ of children who have been ventilated for life threatening asthma episodes have persistent food allergies compared with $<10 \%$ of controlled mild asthmatics. ${ }^{16}$ If high risk children with asthma are identified, it may be possible to target limited resources to treat and monitor these patients more intensively than those at lower risk.

An accurate allergy diagnosis also allows specific immunotherapies (SIT) to be initiated. SIT has been used successfully in treating bee and wasp hypersensitivity ${ }^{17}{ }^{18}$ and grass pollen allergy. ${ }^{19} 20$

A variety of new molecular approaches to treating allergic disease are currently being considered, and many of these have an allergen specific basis. For example, immunostimulatory DNA conjugated with Amb al has been used to treat ragweed sensitivity with positive results. ${ }^{21}$ Other new approaches include the use of anti-IgE therapy, which has been shown to decrease peanut sensitivity markedly. ${ }^{22}$

A greater emphasis on correct allergy diagnosis would also be key to a new approach to the management of allergic diseases in the UK. Currently in the UK, patients with allergic conditions may be under the care of several consultants (for example, respiratory, dermatology, gastroenterology, and ear, nose, and throat specialists), who may not necessarily have had extensive allergy training. An alternative approach would be to have such patients under the care of an allergist working in partnership with other consultants as needed. Such recommendations have recently been made in a special report by the Royal College of Physicians (RCP). ${ }^{23}$ A recent study has shown that specialist intervention in children with food allergies is associated with a decreased number of allergic reactions and increased parental knowledge, thus indicating the potential patient benefits of such an approach. $^{24}$

\section{The allergic march}

Appropriate intervention may help to stop the allergic march. ${ }^{20}$ Nishioka and co-workers reduced dust mite exposure in infants with atopic dermatitis who were sensitised to egg, milk, or soybean, but not house dust mite. ${ }^{26}$ After 1 year, this group showed a significantly lower increase in levels of IgE to house dust mite than a control group $(0.7 \mathrm{v}$ $2.5 \mathrm{U} / \mathrm{ml}$ ). In another study, treatment with cetirizine has been shown to delay, and in some cases prevent, the development of asthma in children with atopic dermatitis (fig 2). ${ }^{27}$ In the Preventative Allergy Treatment study, pollen immunotherapy in patients with seasonal rhinoconjunctivitis reduced the development of co-morbid asthma. ${ }^{20}$

\section{WHAT PROPORTIONS OF PATIENTS WITH COMMON SYMPTOMS HAVE AN ALLERGY?}

\section{Asthma/wheeze}

Asthma that begins early in life is usually associated with atopy, and the prevalence of $\operatorname{IgE}$ mediated wheeze and asthma tends to increase with age (fig 3). Indeed, sensitisation to allergens such as pollen in young children seems to be an important factor in the development of persistent and severe asthma. ${ }^{28} 29$
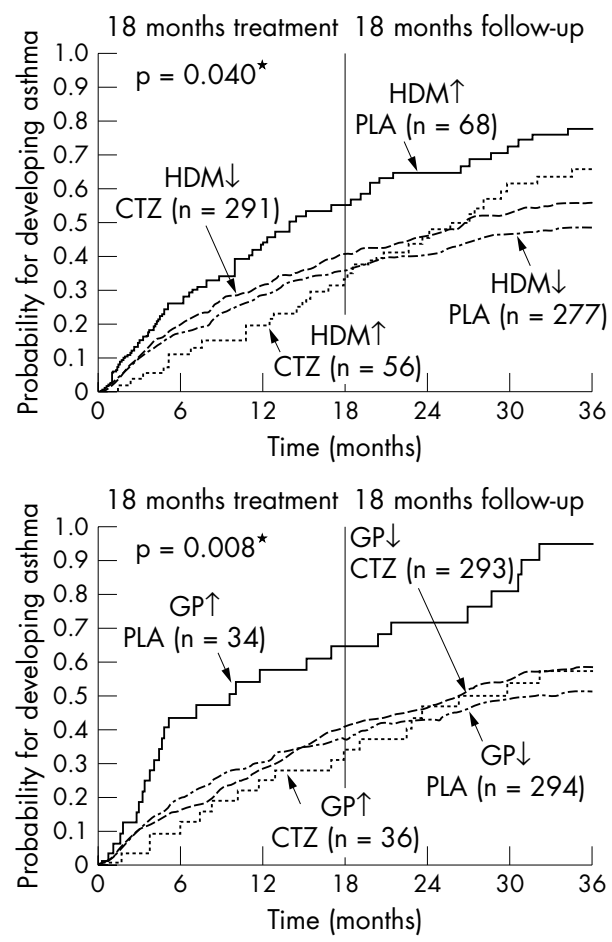

Figure 2 Kaplan-Meier estimates of the development of asthma in children with atopic dermatitis treated with cetirizine (CTZ) or placebo (PLA). HDM $\uparrow$, specific IgE to house dust mite (HDM) $\geqslant 0.35 \mathrm{kUA} / \mathrm{l}$; $\mathrm{HDM} \downarrow$, specific $\lg E$ to $\mathrm{HDM}<0.35 \mathrm{kUA} / \mathrm{l} ; \mathrm{GP} \uparrow$, specific $\lg \mathrm{E}$ to grass pollen $(G P) \geqslant 0.35 \mathrm{kUA} / \mathrm{l}$; GP $\downarrow$, specific lgE to GP $<0.35 \mathrm{kUA} / \mathrm{l}$. Reproduced from Warner. ${ }^{27}$ 


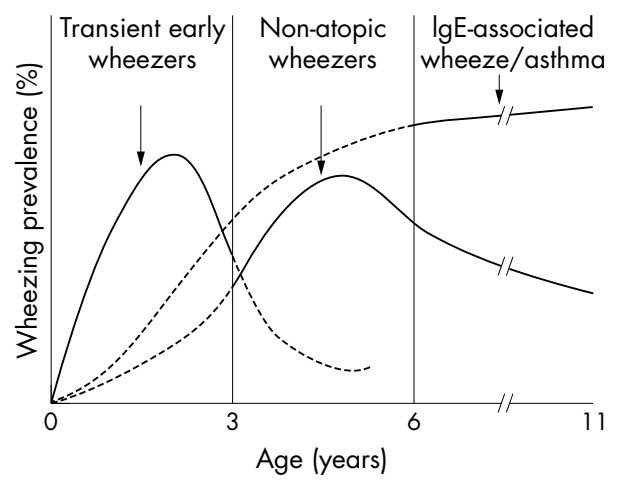

Figure 3 Prevalence of wheeze, and of atopic and non-atopic asthma. Reproduced from Martinez (2002). ${ }^{28}$

Against this background, it must be stressed that not all early wheezing is due to allergy. Indeed, data suggest that only approximately one third of young children with wheeze are allergic. For example, a UK study evaluating the development of allergic diseases in 4 year old children suggests that only $29 \%$ of children with persistent wheeze are sensitive to at least one common aeroallergen. ${ }^{30}$ Other studies report similar results. ${ }^{31} 32$

In older children, however, allergy is more commonly associated with wheezing, with studies reporting the proportion of children with allergic asthma to be about two thirds. ${ }^{2}{ }^{30-38}$ Although there is reasonable agreement between studies from different countries that allergy is usually the cause of asthma and wheezing (table 1), environmental factors such as air pollution and cigarette smoke can play a role. This is illustrated by a study of Swedish and Estonian children with wheeze in which the proportion of children with positive skin prick tests was 58\% in Sweden and 26\% in the less affluent Estonia. ${ }^{34}$

\section{Rhinitis}

A large proportion of patients with rhinitis have mixed rhinitis-that is, coexisting allergic and non-allergic disease. The prevalence of non-allergic rhinitis in children has been reported to be $25-52 \%{ }^{39-41}$ The proportion of patients with rhinitis who are allergic increases with age. Evidence for this comes from an Italian study that assessed 564 children aged 5 months to 17 years who had respiratory symptoms (rhinitis or asthma). ${ }^{31}$ When the data were analysed by age, the proportion of sensitised patients was shown to increase from about $30 \%$ in the group aged 5 months to 4 years age group up to $85 \%$ in the $10-17$ year old age group.

\begin{tabular}{|c|c|c|}
\hline Reference & Population & $\begin{array}{l}\text { Proportion } \\
\text { with } \\
\text { allergy (\%) }\end{array}$ \\
\hline Downs et al & $\begin{array}{l}\text { Australian children who had } \\
\text { wheezed in the past } 12 \text { months }\end{array}$ & 66 \\
\hline $\begin{array}{l}\text { Mortz et } a^{\beta 3} \\
\text { Tariq et } a^{\beta 0}\end{array}$ & $\begin{array}{l}\text { Danish children with asthma } \\
\text { UK children who developed } \\
\text { wheeze after infancy }\end{array}$ & $\begin{array}{l}74 \\
50\end{array}$ \\
\hline Crimi ef $a^{\beta 5}$ & Italian children with lifetime asthma & 66 \\
\hline Norrman et $a^{\beta 7}$ & Swedish boys with asthma & 63 \\
\hline Martinez et $a^{\beta 6}$ & $\begin{array}{l}\text { Swedish girls with asthma } \\
\text { US children with persistent wheeze }\end{array}$ & $\begin{array}{l}83 \\
51\end{array}$ \\
\hline & US children with late-onset wheeze & 56 \\
\hline
\end{tabular}

Is allergy more common in patients with seasonal rhinitis? Although it might be expected that this would be the case, one study indicated that $56 \%$ of children with perennial rhinitis were sensitised to aeroallergens, compared with $61 \%$ of children with seasonal rhinitis. ${ }^{35}$

Data vary, but it can be concluded that a significant proportion of children, particularly young children, with rhinitis are not allergic. Perhaps surprisingly, this may be true regardless of whether the patient has seasonal or perennial symptoms. ${ }^{42} 43$

\section{Eczema}

The role of allergy in eczema has been assessed in a number of studies. In a UK birth cohort study involving 1456 children aged 4 years, ${ }^{4}$ the prevalence of allergy in children with eczema was $43 \%$, with house dust mite, grass pollen, and cat being the most common allergens to which children were sensitised. A German study comparing the prevalence of allergic eczema in 1273 pre-school children in the former East and West Germany over a 7 year period ${ }^{44}$ showed similar results to the UK study. By comparison, the authors of hospital based studies from Hungary and France have estimated the proportion of patients with allergic eczema to be $54 \%$ and $85 \%$, respectively. ${ }^{46}{ }^{47}$

Food allergies often trigger episodes of allergic eczema in children. In one study involving infants and children with atopic eczema, food allergy was shown to play a pathological role in about $40 \%$ of infants and young children with mild to moderate disease..$^{48}$ In a retrospective analysis from a double blind, placebo controlled German study, food challenge tests were evaluated in 107 children with atopic eczema. ${ }^{49}$ The proportion of children who displayed a clinical reaction to at least one food challenge was found to be as high as $81 \%$. Other studies have shown that the proportion of patients with food sensitisation ranges from 50 to $65 \% .^{50} 51$ Seven foods (milk, egg, peanut, soy, wheat, cod, and cashew) appear to be responsible for $89 \%$ of positive test results. ${ }^{50}$ Although food allergy and allergic eczema often resolve in early childhood, such individuals are at risk of developing other allergic sensitivities and atopic diseases, particularly asthma (fig 4).

Sensitivities to aeroallergens are also not uncommon in patients with allergic eczema. German researchers investigated the relationship between IgE mediated allergic sensitisation to aeroallergens (grass and birch pollen, dust mite, and cat) and the severity of allergic eczema in school age children. ${ }^{52}$ More children with allergic eczema were sensitised to each of the aeroallergens than children with no skin disease $(75 \vee 25 \%)$. In addition, the degree of sensitisation was directly associated with the severity of allergic eczema.

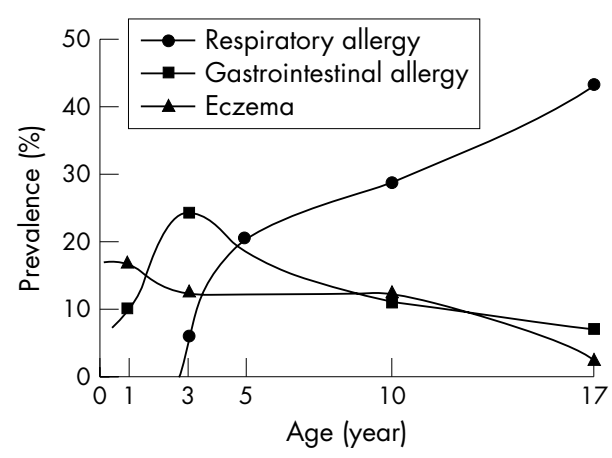

Figure 4 The "allergic march" - allergic disease progression. Reproduced from Saarinen et al. ${ }^{72}$ 


\section{OTHER CAUSES OF COMMON SYMPTOMS Asthma/wheeze}

Childhood wheezing may be allergic in nature, but in many children it results from infection or bronchiolitis. Transient early wheezing, which usually resolves by the time the child reaches 3 years of age, is not generally associated with atopy or any allergic sensitisation. ${ }^{53} \mathrm{In}$ fact, the main risk factor for transient early wheezing is reduced pulmonary function. ${ }^{28} 54$ Furthermore, many school age children with asthma have a history of airway obstruction in the first 2 years of life. ${ }^{55} 56$ This airway obstruction in infancy is most frequently associated with viral infections, such as respiratory syncytial virus. $^{29}$ Viral infections, in combination with allergen exposure, may also play a key role in atopic asthma, in particular by precipitating exacerbations..$^{58}$

\section{Rhinitis}

Non-allergic rhinitis is a broad term covering a range of nasal diseases, both infectious and non-infectious (table 2). ${ }^{43}$ Patients with rhinitis symptoms may also have coexisting allergic and non-allergic disease. Chronic rhinitis is often accompanied by sinusitis. In children this often leads to adenoidal hypertrophy, with symptoms of mouth breathing and snoring.

\section{Eczema}

Non-allergic eczema can result from drug treatments, irritation (contact dermatitis) and emotional stress. Despite this, the terms eczema (encompassing allergic and nonallergic eczema) and atopic dermatitis are often used interchangeably.

\section{MAKING THE CORRECT DIAGNOSIS: HOW AND WHEN?}

As one might expect, symptoms resulting from allergy are difficult to distinguish from those without an allergic cause. How then can we determine whether a child is allergic? As with most medical conditions, the starting point for diagnosing allergy is a careful clinical history and physical examination.

The clinical history should help to answer the following questions: ${ }^{59}$

1. Is the patient likely to be allergic?

2. If allergy is suspected, which allergens are involved?

In practice, this is often best achieved using a questionnaire that parents can fill in at home. Careful questioning can reveal much about the condition and ensure that the clinical history is accurate.

The value of a rigorous clinical history in helping to identify allergy has been assessed. In one study, negative diagnoses made during the clinical history were confirmed in $77 \%$ of patients by a negative provocation test. ${ }^{60}$ Positive

Table 2 Classification of rhinitis

\begin{tabular}{|c|c|c|}
\hline Allergic & Infectious & $\begin{array}{l}\text { Non-infectious/ } \\
\text { non-allergic }\end{array}$ \\
\hline $\begin{array}{l}\text { Seasonal } \\
\text { Perennial }\end{array}$ & $\begin{array}{l}\text { Acute } \\
\text { Chronic }\end{array}$ & $\begin{array}{l}\text { Idiopathic } \\
\text { Non-allergic rhinitis with } \\
\text { eosinophilia syndrome }\end{array}$ \\
\hline Occupational & $\begin{array}{l}\text { Specific } \\
\text { Non-specific }\end{array}$ & $\begin{array}{l}\text { Occupational } \\
\text { Hormonal } \\
\text { Drug induced } \\
\text { Irritants } \\
\text { Food } \\
\text { Emotional } \\
\text { Atrophic }\end{array}$ \\
\hline
\end{tabular}

provocation tests occurred in $64 \%$ of patients with a positive clinical history diagnosis. Although valuable, a good clinical history is not definitive. In these circumstances, the options available are the detection of IgE antibodies in blood and the performance of skin prick, skin patch and double blind, placebo controlled food challenge (DBPCFC) tests. The presence of raised total serum $\operatorname{IgE}^{61}$ and a peripheral eosinophilia further increases the chance of the individual being sensitised to allergen(s).

Unfortunately, total serum IgE tests may give false positive and negative results for specific allergies. Frequently, children with individual allergies present with normal total serum IgE levels. The preferred approach for allergy diagnosis should therefore be to use testing that is based on an allergic history. Tests that measure specific allergies should be chosen on the basis of the physician's knowledge of the allergens that are statistically most likely to cause symptoms in different age groups. Knowledge of seasonal allergens and how these differ regionally is also important. Nevertheless, it may be difficult to obtain an accurate history, particularly in young infants. Here, an IgE screening test, such as Phadiatop, which assesses specific IgE levels in response to a range of common allergens, may be extremely useful. If this test is positive, further specific testing can then be used to identify the relevant allergen(s).

Immediate hypersensitivity to allergens can be determined either by specific IgE measurements or by skin prick testing. Patch testing is not useful in this regard, but can be used to diagnose of contact dermatitis. Specific IgE and skin prick testing should not be seen as mutually exclusive, but rather as complementary techniques that can corroborate diagnosis. Skin prick testing provides a rapid form of assessing allergies in a clinical context. The advantages of specific IgE testing are that multiple tests can be performed on the same blood sample and that the technique is not influenced by use of antihistamines or the presence of dermatographism. In addition, blood samples can be stored and reanalysed should further allergic symptoms present. However, the technique suffers from several drawbacks. Patients (particularly children) will only tolerate a limited number of tests, and numerous children who are receiving antihistamine treatment cannot be tested. Furthermore, patients with dermatographism give false positive results to skin prick tests, and food allergen extracts are not standardised, therefore different product batches may give different results. Patients with a very high total IgE level may exhibit multiple positive specific IgE tests with a high chance of false positive results. However, the increasing use of the new generation of in vitro tests with greater sensitivity and specificity ${ }^{62}$ means that this effect is now infrequent.

Interpretation of both specific IgE testing and skin prick testing requires a certain level of training and experience. Furthermore, an appreciation of the sensitivity and specificity, as well as the positive and negative predictive values, of these tests for different allergens and in different populations is desirable. Not all children with positive tests for food specific IgE have clinical sensitivity. This is seen in children

Table 3 Diagnostic (>95\% certainty) lgE levels for major food allergies ${ }^{63} 64$

\begin{tabular}{ll}
\hline Allergen & $\begin{array}{l}\text { Diagnostic lgE } \\
\text { level (kU/I) }\end{array}$ \\
\hline Egg & 6 \\
Cow's milk & 32 \\
Peanuts & 15 \\
Fish & 20 \\
\hline
\end{tabular}


who have become clinically tolerant to milk or egg, but maintain positive skin test results. Detailed evaluation of results may require specialist knowledge.

Of relevance to food allergy, there are diagnostic criteria for IgE tests for a number of major food allergens (table 3). ${ }^{6364}$ DBPCFC is the gold standard for suspected food hypersensitivity. However, it is time consuming, and as it is associated with potential risks, it should always be performed by a specialist. ${ }^{65}$ In order to reduce the need for DBPCFC, positive predictor values for different levels of IgE antibodies have been determined for certain foods. ${ }^{64}$ Food specific IgE concentrations have been established that can predict clinical reactivity to egg, cow's milk, peanuts, and fish with $>95 \%$ certainty. The use of $95 \%$ and $100 \%$ positive predictive values has been shown to be effective in predicting existing clinical reactivity and reducing the need for food challenge in children with food sensitivity ${ }^{63}{ }^{66}$ Positive predictive cut offs for food allergy skin prick tests have also been reported. ${ }^{67} 68$ However, it is important to remember that patients with IgE antibody levels below such cut off values or even with no measurable specific IgE may be allergic.

A preliminary UK study has explored how allergy tests facilitate the work of allergy nurses in general practice and how this influences the advice they offer. ${ }^{69}$ Most nurses in the study thought that allergy testing was valuable, easy to perform, and could be readily incorporated into existing work routines. The nurses' decision about whether to give advice on allergy avoidance was reversed in $13-22 \%$ of cases. If allergy avoidance interventions had been targeted only at patients with a positive allergy test and a positive clinical history, the number of planned interventions would have decreased by $53 \%$. This suggests that allergy testing may have considerable benefits in general practice.

The more widespread use of allergy testing may have resource implications. However, we believe the cost of testing should be offset by the reduced costs associated with avoiding inappropriate treatment and the benefits to patients associated with appropriate management of their symptoms.

\section{THE ROLE OF PRIMARY CARE IN ALLERGY MANAGEMENT}

Because of the scale of the problem, the need for primary care to provide frontline care for patients with allergy has been recognised in the recent RCP report..$^{23}$ This report highlights the current lack of specialist allergists in the UK and notes that primary care physicians are not trained sufficiently in the management of allergic diseases. Indeed, results from a random sample of 240 UK GPs, surveyed by questionnaire, reveal that most expressed concern about their ability to diagnose and manage children with allergic problems. ${ }^{70}$ Given the prevalence of allergic disorders, these findings represent serious problems that must be addressed if management of allergic conditions is to improve. The RCP report proposes the development of primary care physicians with a special interest in allergy who undergo training that is linked to regional allergy centres. The regional allergy centres should provide secondary and tertiary care for both adults and children, and support the training of primary care physicians and nurses so that they gain greater expertise.

\section{CONCLUSIONS}

Conditions commonly referred to as allergic diseases (asthma, rhinitis, and eczema) often occur in patients who do not have an allergy. It is important that a differential diagnosis between allergic and non-allergic disease is made so that the appropriate management strategy can be implemented ${ }^{71}$ A positive allergy diagnosis will allow specific treatments, as well as allergen avoidance, to be initiated. Negative allergy diagnosis will help to prevent unnecessary trials of various medications, allow further diagnostic investigations, and reduce the number of allergen avoidance interventions offered to children who will not benefit from them.

A rigorous clinical history and careful physical examination can point towards the presence of an allergy, but specific tests may be needed. A number of options are available, but testing for allergen specific IgE, either by skin test or in vitro testing, is the best option for physicians who would not consider themselves allergy specialists.

The use of allergy testing to identify children with eczema, asthma, wheeze, or rhinitis with an allergic basis should help to improve the management of these conditions. By providing an indication of appropriate avoidance strategies to relieve symptoms and potentially delay or prevent the onset of further allergic manifestations, healthcare resources may also be directed more appropriately.

\section{Authors' affiliations}

S Holgate, Division of Infection, Inflammation and Repair, School of Medicine, University of Southampton, Southampton, UK

G Lack, Paediatric Allergy abd Immunology, St Mary's Hospital, London, UK

Competing interests: none

\section{REFERENCES}

1 Burr ML, Butland BK, King S, et al. Changes in asthma prevalence: two surveys 15 years apart. Arch Dis Child 1989;64:1452-6.

2 Downs SH, Marks GB, Sporik R, et al. Continued increase in the prevalence of asthma and atopy. Arch Dis Child 2001;84:20-3.

3 Ninan TK, Russell G. Respiratory symptoms and atopy in Aberdeen schoolchildren: evidence from two surveys 25 years apart. $\mathrm{Br}$ Med $J$ 1992;304:873-5.

4 Arshad SH, Tariq SM, Matthews S, et al. Sensitization to common allergens and its association with allergic disorders at age 4 years: a whole population birth cohort study. Pediatrics 2001;108:e33.

5 Duran-Tauleria E, Vignati G, Guedan MJ, et al. The utility of specific immunoglobulin $\mathrm{E}$ measurements in primary care. Allergy 2004;59(suppl 78):35-41

6 Carswell F, Birmingham K, Oliver J, et al. The respiratory effects of reduction of mite allergen in the bedrooms of asthmatic children-a double-blind controlled trial. Clin Exp Allergy 1996;26:386-96.

7 Gillies DR, Littlewood JM, Sarsfield JK. Controlled trial of house dust mite avoidance in children with mild to moderate asthma. Clin Allergy 1987;17:105-11.

8 Murray $A B$, Ferguson $A C$. Dust-free bedrooms in the treatment of asthmatic children with house dust or house dust mite allergy: a controlled trial. Pediatrics 1983;71:418-22.

9 van der Heide S, Kauffman HF, Dubois $A E$, et al. Allergen-avoidance measures in homes of house-dust-mite-allergic asthmatic patients: effects of acaricides and mattress encasings. Allergy 1997;52:921-7.

10 Gore RB, Custovic A. Is allergen avoidance effective? Clin Exp Allergy 2002;32:662-6.

11 Carter MC, Perzanowski MS, Raymond A, et al. Home intervention in the treatment of asthma among inner-city children. J Allergy Clin Immunol 2001;108:732-7

12 Agata $\mathrm{H}$, Kondo $\mathrm{N}$, Fukutomi $\mathrm{O}$, et al. Effect of elimination diets on foodspecific $\lg E$ antibodies and lymphocyte proliferative responses to food antigens in atopic dermatitis patients exhibiting sensitivity to food allergens. $J$ Allergy Clin Immunol 1993;91:668-79.

13 Atherton DJ, Sewell M, Soothill JF, et al. A double-blind controlled crossover trial of an antigen-avoidance diet in atopic eczema. Lancet 1978;1:401-3.

14 Host A, Husby S, Hansen LG, et al. Bovine beta-lactoglobulin in human milk from atopic and non-atopic mothers. Relationship to maternal intake of homogenized and unhomogenized milk. Clin Exp Allergy 1990;20:383-7.

15 Isolauri E, Tahvanainen A, Peltola T, et al. Breast-feeding of allergic infants. J Pediatr 1999;134:27-32.

16 Roberts G, Patel N, Levi S, et al. Food allergy as a risk factor for lifethreatening asthma in childhood: a case-controlled study. J Allergy Clin Immunol 2003; 1 12:168-74.

17 Bousquet J, Lockey R, Malling $\mathrm{HJ}$, et al. Allergen immunotherapy: therapeutic vaccines for allergic diseases. World Health Organization. American academy of Allergy, Asthma and Immunology. Ann Allergy Asthma Immunol 1998;81:401-5.

18 Hunt KJ, Valentine MD, Sobotka AK, et al. A controlled trial of immunotherapy in insect hypersensitivity. N Engl J Med 1978;299:157-61.

19 Durham SR, Walker SM, Varga EM, et al. Long-term clinical efficacy of grasspollen immunotherapy. N Engl J Med 1999;341:468-75.

20 Möller C, Dreborg S, Ferdousi HA, et al. Pollen immunotherapy reduces the development of asthma in children with seasonal rhinoconjunctivitis (the PATstudy). J Allergy Clin Immunol 2002;109:251-6. 
21 Creticos PS, Lighvani SS, Bieneman AP, et al. Enhanced IL-10 secretion by PBMC during the ragweed season: effect of AIC immunotherapy vs. placebo. J Allergy Clin Immunol 2003;111:A530.

22 Leung DY, Sampson HA, Yunginger JW, et al. Effect of anti-lgE therapy in patients with peanut allergy. N Engl J Med 2003;348:986-93.

23 Royal College of Physicians. Allergy: the unmet need: a blue print for better patient care, Report of the Royal College of Physicians working party on the provision of allergy services in the UK. London: RCP, 2003.

24 Kapoor S, Roberts G, Bynoe Y, et al. Influence of a multidisciplinary paediatric allergy clinic on parental knowledge and rate of subsequent allergic reactions. Allergy 2004;59:185-91.

25 Wahn U, Bergmann RL, Nickel R. Early life markers of atopy and asthma. Clin Exp Allergy 1998;28(suppl 1):20-1.

26 Nishioka K, Yasueda H, Saito H. Preventive effect of bedding encasement with microfine fibers on mite sensitization. J Allergy Clin Immunol 1998; 101:28-32.

27 Warner JO. A double-blinded, randomized, placebo-controlled trial of cetirizine in preventing the onset of asthma in children with atopic dermatitis: 18 months' treatment and 18 months' posttreatment follow-up. J Allergy Clin Immunol 2001;108:929-37.

28 Martinez FD. Development of wheezing disorders and asthma in preschool children. Pediatrics 2002;109:362-7.

29 Peat JK, Salome CM, Woolcock AJ. Longitudinal changes in atopy during a 4 year period: relation to bronchial hyperresponsiveness and respiratory symptoms in a population sample of Australian schoolchildren. J Allergy Clin Immunol 1990;85:65-74.

30 Tariq SM, Matthews SM, Hakim EA, et al. The prevalence of and risk factors for atopy in early childhood: a whole population birth cohort study. J Allergy Clin Immunol 1998;101:587-93.

31 Silvestri M, Oddera S, Rossi GA, et al. Sensitization to airborne allergens in children with respiratory symptoms. Ann Allergy Asthma Immunol 1996; 76:239-44.

32 Haby MM, Peat JK, Marks GB, et al. Asthma in preschool children: prevalence and risk factors. Thorax 2001;56:589-95.

33 Mortz CG, Lauritsen JM, Bindslev-Jensen C, et al. Prevalence of atopic dermatitis, asthma, allergic rhinitis, and hand and contact dermatitis in adolescents. The Odense Adolescence Cohort Study on Atopic Diseases and Dermatitis. Br J Dermatol 2001;144:523-32.

34 Annus T, Bjorksten B, Mai XM, et al. Wheezing in relation to atopy and environmental factors in Estonian and Swedish schoolchildren. Clin Exp Allergy 2001;31:1846-53.

35 Crimi P, Minale P, Tazzer C, et al. Asthma and rhinitis in schoolchildren: the impact of allergic sensitization to aeroallergens. J Investig Allergol Clin Immunol 2001;11:103-6.

36 Martinez FD, Wright AL, Taussig LM, et al. Asthma and wheezing in the first six years of life. The Group Health Medical Associates. N Engl J Med 1995;332:133-8.

37 Norrman E, Rosenhall L, Nyström L, et al. Prevalence of positive skin prick tests, allergic asthma, and rhinoconjunctivitis in teenagers in northern Sweden. Allergy 1994;49:808-15.

38 Ponsonby AL, Gatenby P, Glasgow N, ef al. Which clinical subgroups within the spectrum of child asthma are attributable to atopy? Chest 2002;121:135-42.

39 Enberg RN. Perennial nonallergic rhinitis: a retrospective review. Ann Allergy 1989;63:513-16.

40 Leynaert B, Bousquet J, Neukirch C, et al. Perennial rhinitis: An independent risk factor for asthma in nonatopic subjects: results from the European Community Respiratory Health Survey. J Allergy Clin Immunol 1999;104:301-4.

41 Mullarkey MF, Hill JS, Webb DR. Allergic and nonallergic rhinitis: their characterization with attention to the meaning of nasal eosinophilia. J Allergy Clin Immunol 1980;65:122-6.

42 Wever-Hess J, Kouwenberg JM, Duiverman EJ, et al. Prognostic characteristics of asthma diagnosis in early childhood in clinical practice. Acta Paediatr 1999;88:827-34.

43 Settipane RA. Demographics and epidemiology of allergic and nonallergic rhinitis. Allergy Asthma Proc 2001;22:185-9.

44 Schafer $T$, Vieluf $D$, Behrendt $H$, et al. Atopic eczema and other manifestations of atopy: results of a study in East and West Germany. Allergy 1996:51:532-9.
45 Schafer T, Kramer U, Vieluf D, et al. The excess of atopic eczema in East Germany is related to the intrinsic type. Br J Dermatol 2000;143:992-8. 46 Somos Z, Schneider I. (Serum and secretory immunoglobulins in atopic dermatitis). Orv Hetil 1993;134:1359-61.

47 Cabon N, Ducombs G, Mortureux P, et al. Contact allergy to aeroallergens in children with atopic dermatitis: comparison with allergic contact dermatitis. Contact Dermatitis 1996;35:27-32.

48 Sicherer SH, Sampson HA. Food hypersensitivity and atopic dermatitis: pathophysiology, epidemiology, diagnosis, and management. J Allergy Clin Immunol 1999;104:S114-22.

49 Niggemann B, Sielaff B, Beyer K, et al. Outcome of double-blind, placebocontrolled food challenge tests in 107 children with atopic dermatitis. Clin Exp Allergy 1999;29:91-6.

50 Burks AW, James JM, Hiegel A, et al. Atopic dermatitis and food hypersensitivity reactions. J Pediatr 1998;132:132-6.

51 Resano A, Crespo E, Fernandez B, et al. Atopic dermatitis and food allergy $J$ Investig Allergol Clin Immunol 1998;8:271-6.

52 Schäfer T, Heinrich J, Wist $M$, et al. Association between severity of atopic eczema and degree of sensitization to aeroallergens in schoolchildren. J Allergy Clin Immunol 1999; 104:1280-4.

53 Wright AL. Epidemiology of asthma and recurrent wheeze in childhood. Clin Rev Allergy Immunol 2002;22:33-44.

54 Martinez FD. Role of respiratory infection in onset of asthma and chronic obstructive pulmonary disease. Clin Exp Allergy 1999;29(suppl 2):53-8.

55 Pearce N, Pekkanen J, Beasley R. How much asthma is really attributable to atopy? Thorax 1999;54:268-72.

56 Yunginger JW, Reed CE, Connell EJ, et al. A community-based study of the epidemiology of asthma. Incidence rates, 1964-1983. Am Rev Respir Dis 1992;146:888-94.

57 Green RM, Custovic A, Sanderson G, et al. Synergism between allergens and viruses and risk of hospital admission with asthma: case-control study. BMJ 2002;324:763.

58 Johnston SL, Pattemore PK, Sanderson G, et al. Community study of role of viral infections in exacerbations of asthma in 9-11 year old children. BMJ 1995;310:1225-9.

59 Eriksson NE. Diagnosis of lgE mediated allergy in clinical practise. Allergol Immunopathol (Madr) 1994;22:139-51.

60 Eriksson NE. Diagnosis of reaginic allergy with house dust, animal dander and pollen allergens in adult patients. III. Case histories and combinations of case histories, skin tests and the radioallergosorbent test, RAST, compared with provocation tests. Int Arch Allergy Appl Immunol 1977:53:441-9.

61 Sanz ML, Prieto I, Garcia BE, et al. Diagnostic reliability considerations of specific lgE determination. J Investig Allergol Clin Immunol 1996;6:152-61.

62 Cots $\mathbf{P}$, Pena JM, Botey J, et al. Determination of total and specific lgE using UNICAP 100: comparative study with the CAP system. Allergol Immunopathol (Madr) 1998;26:223-7.

63 Sampson HA. Utility of food-specific lgE concentrations in predicting symptomatic food allergy. J Allergy Clin Immunol 2001;107:891-6.

64 Sampson HA, Ho DG. Relationship between food-specific IgE concentrations and the risk of positive food challenges in children and adolescents. J Allergy Clin Immunol 1997; 100:444-51.

65 Sicherer SH. Food allergy. Lancet 2002;360:701-10.

66 Hill DJ, Hosking CS, Reyes-Benito LV. Reducing the need for food allergen challenges in young children: a comparison of in vitro with in vivo tests. Clin Exp Allergy 2001;31:1031-5.

67 Sporik R, Hill DJ, Hosking CS. Specificity of allergen skin testing in predicting positive open food challenges to milk, egg and peanut in children. Clin Exp Allergy 2000;30:1540-6.

68 Roberts G, Lack G. Food allergy - getting more out of your skin prick tests. Clin Exp Allergy 2000;30:1495-8.

69 Sibbald B, Barnes G, Durham SR. Skin prick testing in general practice: a pilot study. J Adv Nurs 1997;26:537-42.

70 Levy ML, Price $D$, Zheng $X$, et al. Inadequacies in UK primary care allergy services: national survey of current provisions and perceptions of need. Clin Exp Allergy 2004:34:518-19.

71 Høst A, Andrae S, Charkin S, et al. Allergy testing in children: why, who, when and how? Allergy 2003;58:559-69.

72 Saarinen UM, Kajosaari M. Breastfeeding as prophylaxis against atopic disease: prospective follow-up study until 17 years old. Lancet 1995;346:1065-9. 